\title{
IMPROVING MANAGEMENT \& PRACTICE IN AU PAIR INDUSTRY: SYSTEMS OVERVIEW, FROM A CENTRAL EUROPE-U.S. PERSPECTIVE
}

\author{
Barbara A. Manko* (D) https://orcid.org/0000-0001-6916-5717 \\ Jerzy Rosiński** (iD https://orcid.org/ 0000-0002-8348-2839 \\ Tony R. Johns*** (iD https://orcid.org/0000-0003-4701-7072
}

\begin{abstract}
Recruiting agencies in Central Europe partner with various companies in the United States to place young women and men (ages 18-26) from their countries into the homes of U.S. families as au pairs, i.e., live-in child care providers. Ideally, the arrangement combines cultural exchange with useful services, to the benefit of all. However, many "matches" do not go well. In over one-fourth of the cases surveyed for this paper, the au pair did not complete the agreed-upon stay with the U.S. host family, often leaving at the family's insistence. These failures are harmful to the persons involved as well as to the Central European recruiting agencies and the U.S. companies they work with. This paper examines how success rates could be improved through better practices by all concerned. Success factors include: setting realistic expectations for au pair candidates and host families, coaching them for online interviews (including optimum use of the technology), and providing strong follow-up support. Research for the paper included a survey of U.S. host families and comparative studies of sources such as news reports, academic publications, public websites used in the au pair industry, and other materials.
\end{abstract}

Background. Recruiting agencies in Central Europe partner with various companies in the United States to place young women and men (ages 18-26) from their countries into the homes of U.S. families as au pairs, i.e., live-in child care providers. Ideally, the arrangement combines cultural exchange with useful services, to the benefit of all. However, in over one-fourth of the cases surveyed for this paper, the au pair did not complete the agreed-upon stay with the U.S. host family, often leaving at the family's insistence.

* Penn State University Clarion University of Pennsylvania. E-mail: bam43@psu.edumanko@clarion.edu.

** Jagiellonian University in Kraków. E-mail: jerzy.rosinski@uj.edu.pl.

*** Clarion University of Pennsylvania. E-mail: johns@clarion.edu. 
Research aims. This paper examines how success rates could be improved through better practices. Success factors include: setting realistic expectations for au pair candidates and host families, coaching them for online interviews and providing strong follow-up support.

Methodology. A survey of U.S. host families and comparative studies of multiple sources, e.g., news reports, academic publications, public websites from au pair industry.

Key findings. A successful placement gives the au pair valuable career experience, enhances the home country's human capital and its image abroad, helps Central European agents recruit further good candidates. Failures impose financial losses, burdens on all parties. It can damage the au pair's morale and create obstacles in one's path to a productive career.

Keywords: leisure time industry, intercultural cooperation, au pair, globalization.

JEL Codes: M11, M15.

\section{INTRODUCTION}

The traditional practice of au pair service has grown into a global industry. During recent decades, increasing numbers of young women and men from countries around the world have been placed each year with families in other countries as temporary, live-in child care providers (e.g., Cox, 2015; IAPA, 2018). Companies have been formed in nearly every part of the world to manage processes that once were done informally, among local networks of friends: the recruiting of au pairs, and placing or "matching" them with host families. Companies also provide related services such as training, follow-up support, and compliance with legal or visa standards in the various countries (AuPairCare, 2019).

To give some glimpses of the industry's scale, Germany in 2017 admitted a record number of 13,500 young foreign persons as au pairs (IAPA, 2018), while the United States - a much larger country, but one that adopted the practice more recently - has been admitting more than 20,000 per year (Slevin, 2019). Further, the flows go in all directions between various countries: au pairs from Germany are among those serving in the U.S. and vice versa.

This study focuses on the matching of foreign au pairs with U.S. host families, with a particular emphasis on the implications for the recruiting and placement of Central European au pairs, i.e., those who come to the U.S. from countries including Germany, Poland, Czech Republic, Slovakia, Ukraine, Lithuania, Austria, Hungary, Slovenia, and Romania. 
And to put the problem statement simply: Many of the matches do not work out. A survey done for this paper found that $27 \%$ of au pairs did not complete the full duration of their assignments, either due to the family's dissatisfaction or discontent on the part of the au pair (Appendix A has tables and charts summarizing survey results). This high failure rate is a cause for concern. Failures draw unwanted media attention, and have tangible negative consequences for the persons and companies involved.

There has been little study thus far of the au pair industry as a business system or set of systems. Therefore, as an early step toward developing systemic knowledge, research for this paper has been aimed at identifying: 1) factors that contribute to the failure rate and 2) practices that could convert more failures to successes. Let us start by briefly examining the history and context of the industry that places Central European au pairs with U.S. families.

\section{THE AU PAIR INDUSTRY AND CENTRAL EUROPEAN CONNECTIONS}

The tradition of young women serving as au pairs began in Europe, as shown by the fact that the term is French. It appeared in written use during the early 1800s and means "equal to" or "on a par with" the host family, indicating that the au pair has a different status than a hired nanny or domestic servant (de Balzac, 1840, 2001). The relationship is not merely one of employment. Rather, the young woman and man is to be treated as a temporary member of the family. She is not paid market-rate wages, but does perform certain tasks and is given a home and other considerations during her stay. Over the years, this concept spread across borders in Europe and became more formalized, including elements of intercultural exchange and education. In recent years, young men as well as young women have been placed as au pairs (Lo, 2020). The United States adopted the custom in 1986 (Slevin, 2019).

Au pairs coming the U.S. must be between the ages of 18 and 26 . They are expected to have prior experience in childcare, either through work or informally. Assignments to host families range from 12 to 24 months in length. Specified duties include up to 45 hours per week of caring for the family's child or children, in roles that may include: keeping younger children bathed and properly dressed, 
engaging in play and formative activities with the children, monitoring their safety, transporting and minding them outside the homein short, all that caring parents or guardians might do if they were able to be present (AuPairCare, 2019).

In return, au pairs are to receive multiple benefits. These include weekly stipends for personal expenses, free room and board in the family home, certain days and weeks off, and part-time enrollment in desired courses at a nearby college or university. Au pairs also generally expect to gain exposure to U.S. culture, immersive practice in using English, the chance to build friendships and personal networks - and of course credible experience in performing valued work outside their home country (AuPairCare, 2019).

The terms and conditions described here are essentially uniform across the U.S. au pair industry, as they allow the young women and men to qualify for the visas they need. The host families, by necessity, tend to be affluent. Placement program fees, stipends to the au pair, and other fees currently total around US\$20,000 per year; other expenses can add more (Go Au Pair, 2020). At present more than a dozen U.S. companies are active in placing au pairs with families. They use similar but not identical systems for operating their programs.

American families may prefer au pairs from particular countries. For example, many U.S. residents have ancestral roots in Central European countries. About 16\% identify as partly or wholly of German heritage, 3\% as Polish, and smaller percentages as having Czech, Slovak, Ukrainian, and other Central European ancestries (U.S. Census Bureau, 2019). Given the U.S. population of about 330 million, this translates to large numbers who could be influenced by wanting their children to have contact with an au pair from the land of origin. In 2018, Germany, Poland, and the Czech Republic were among the 20 countries sending the most au pairs to the U.S., while Slovakia and Hungary were among the 20 with largest increases in au pairs sent (U.S. Bureau of Educational and Cultural Affairs, 2019).

Also, Americans of any ancestry can develop perceptions and opinions about the desirability of au pairs from particular countries. Several factors can lead them to favor or at least consider candidates from Central Europe, such as the long European tradition of au pair service, and the fact that European societies are different but not radically different from the U.S., thus minimizing "culture shock". However, perceptions of au pairs from any part 
of the world can be influenced by the comments of host families, which are able to spread widely if the comments are posted online (e.g., Harquail, 2010).

\section{CANDIDATE SELECTION AND PREPARATION IN CENTRAL EUROPE}

The recruiting of au pair candidates in Central Europe is done by independent, in-country agencies such as Prowork Au Pair in Warsaw (Prowork Au Pair, n.d.). To send young women and men to the United States, the agencies work with the U.S. au pair companies on a commission basis. Typical recruiting agents are natives or established residents of the countries they are based in, and have connections and experience that help them identify and prepare suitable candidates. Agents may find candidates initially through personal networks, such as at schools and universities, or through word of mouth referral or advertising, or a combination of methods.

Preparation of the candidates to enter the matching process with the U.S. will be a subject of close examination in the rest of this paper. The matching process, in brief, goes as follows: candidates enter a U.S. company's pool of au pair offerings by having their photos, video, information, and other materials posted on the company's website. Families can then search this online database to find young women or men they would like to interview. Very often the interviews are conducted online via Skype, Facetime, or a similar technology.

Ultimately a match is made, and in the best cases it is a good one. But a failed match has multiple negative impacts.

\section{CONSEQUENCES OF FAILURE}

The host family, of course, must promptly get another means of childcare. The U.S. company stands to lose revenue and reputation while incurring added administrative costs. And for the au pair, the situation is even harder. Her visa gives her two weeks to find a new host family - typically, one that has just lost or discharged their previous au pair. If a new match cannot be found, she/he must leave the U.S. and return home, at her/his own expense. Failure can 
also demoralize the young woman or man, put a mark on her/his record that hurts her/his future prospects, and harm the reputation of au pairs from her/his home country.

For the Central European recruiting agency, a failure means losing part or all of the commission. Further, if au pairs report negative experiences when they return, their comments are likely to spread and discourage future good candidates from seeking au pair service through the agency. Failures can even have negative effects on the Central European home country as a whole. Young women and men are attracted to enter au pair programs, in part, by the promise of experience and global connections that will help them become productive, creative people in the years ahead. To the extent that these benefits are lost, their potential to contribute to their native country's society and economy is diminished.

Meanwhile, demand for au pairs continues to increase, driven by trends such as the growing prevalence of time-intensive professional work by parents in today's economies. Researcher Margaret Burchinal and her colleagues note the extent to which this has normalized the use of secondary childcare: "Many [children] now experience nonparental care. About half of the infants and toddlers and over $75 \%$ of preschoolers in the United States receive regular early education and care by individuals other than their parents" (Burchinal et al., 2015).

Managers in the au pair industry cannot keep up with demand in many cases, and the constant rotation of au pairs who do not match with their host families and seek to be re-matched is a perpetual weight. Thus, the effects of failed matches ripple through the industry in much the same way as the consequences of high defect rates or employee churn rates in other industries. They reduce returns on time and money invested while imposing added burdens all around.

Up to now, managers and recruiting agents in the relatively young au pair industry have used a broad spectrum of methods for the processes that go into selecting au pair candidates and matching them with host families. The candidates and families, for their part, take a variety of approaches to working their way through the system in order to meet their goals. The research for this paper looks at the industry from multiple angles. Its intent is to trace the points where the seeds of failure may be planted, and identify best practices that the various players can use to arrive at more successful outcomes. 


\section{RESEARCH METHODS}

This study is essentially qualitative, as multiple sources are comparatively analyzed to pursue the above-stated goals of identifying failure factors and good practices. The sources include: academic research, credible journalistic research and descriptive articles, websites of companies in the au pair industry, and public websites used by families and au pairs. Additionally, the author and co-author created a survey of host families in the U.S. and drew upon conversations with industry persons helping to implement the survey.

The survey adds a quantitative element. It consisted of questions for the host families about their number and duration of their au pair engagements, the outcomes, and how they approached and did online interviews with candidates to select their au pairs (see Appendix A). The survey was implemented by proxy through a regional manager at a U.S. au pair company. Current methods of selection were used to obtain a sample of host families, who received the survey by email on November 5, 2019. A total of 123 completed surveys were collected and statistically analyzed.

\section{PRESENTATION OF FINDINGS}

The following sections are organized by looking, in turn, at various stages and elements of the processes used in the au pair industry. This allows each section to focus on how things are currently done and what can go wrong, along with practices that correlate to good results or at least show promise. The sections cannot be presented strictly in step-by-step, start-to-finish order, because events may happen in different places at the same time. But we begin by looking at the early stages of the process in Central Europe.

\section{SELECTION OF CANDIDATES IN CENTRAL EUROPE}

Young women and men who want to become au pairs are exposed to messages that may be misleading. Websites of au pair companies emphasize the enjoyable aspects of the experience (e.g., AuPairCare, 2020). Some au pairs arrive in the U.S. with an apparent focus on 
opportunities to socialize (e.g., Harquail, 2012). In short, there are many reported cases of au pair candidates going into the process with unrealistic expectations. To quote a research paper in Feminist Review:

Expecting to be treated as a member of the host family, they were surprised by the amount of work involved and how difficult it was. As one German au pair commented, "Hard as it is to believe, I never thought seriously about the fact that I would be working. It never once occurred to me that I would be working so hard, that looking after three small children would be difficult, frustrating, and tiring" (Hess \& Puckhaber, 2004).

Central European recruiting agencies can help in this regard by making expectations and responsibilities clear to the candidates. Although it may seem obvious, host families seeking "child care" tend to have one priority above all else: the well-being of their children. One research team elaborated on the point as follows: "Parents want caregivers who love and treat their children as if they were their own... [and furthermore]. Caring is associated with mothering, doing for others altruistically" (Yodanis \& Lauer, 2005). Also, recruiters in many industries have listed "passion" or "enthusiasm" for the work as a quality that candidates must have in order to succeed (e.g., Steiber \& Alänge, 2015). From sources like these, we may infer that young women and men who exhibit intense interest and even a "passion" for giving care to children have a key requirement for becoming successful au pairs, while those who show far more interest in other aspects of the role may be headed for problems.

Of course, candidates must also have the requisite skills and qualifications. The point is that checking credentials is not enough. Recruiting agents may be well advised to focus some part of the selection process on candidates' expectations and priorities, selecting those who really want to do what au pairs are most valued for doing. And young women and men should consider this point before putting themselves forth as au pair candidates. 


\section{PREPARATIONS FOR MATCHING, AS PRACTICED IN THE U.S.}

Host families can differ greatly, not only in the numbers and ages of their children, but in terms of the parents' personalities, lifestyle, and type of community and geographic area in which they live. They also differ in expressing the personal qualities they seek most in an au pair. For example, in an in-depth article on choosing an au pair, U.S. journalist Sandra Hando wrote that for one family, "it was about finding someone reliable with a bubbly personality who also liked interacting with children" (Hando, 2017). Other families may prefer an au pair with a calmer and quieter presence, or they may value particular skills, which could range from caring for special-needs children to safe driving (All au pairs in the U.S. must have an international driver's license, but some placements involve little or no driving while in others it is a critical task).

Whatever the case, the mission is to find a good fit. Major au pair companies offer technology for the purpose, in the form of software for searching the company's online database of available au pairs. One company, for example, provides search-and-screening functionality by a host of criteria, including specifics of childcare experience, details of driving experience, personality traits expressed, and au pair preferences on matters such as living with host parents of different religions or sexual orientations (Go $\mathrm{Au}$ Pair, 2020). An executive of another firm emphasized that her company offers both "a customer driven, Web-based matching process... and a Web community with a vast array of helpful information" (Kannon \& Gedarovich, 2009).

Online search can be a great improvement over the old procedure of sifting through resumes by hand, but it is not usually seen as the ultimate matching tool. One mother described the process as "akin to online dating" (Hando, 2017) - i.e., not completely reliable - and in fact it is often used to compile a short list of promising candidates, who will then be interviewed in order to make a final choice. Over $85 \%$ of the host families in our survey (Appendix A) interviewed more than one candidate. The most popular short-list number was two candidates (31.7\%) and other families interviewed as many as five. For the minority who targeted just one candidate, the interview served to confirm their selection. 
The media that families used to communicate with candidates pose some interesting questions. $11.9 \%$ of the families conducted voice interviews by phone, a traditional choice. A greater number, $19.5 \%$, used email, and 8.1\% texted. Apparently, email doesn't work well, as only $4.1 \%$ of families, less than a fourth of those who chose email interviews, said they would recommend it to others. Conversely, text was recommended by $17.1 \%$, more than twice the number who used it as their primary means. At present it is only possible to speculate on the reasons behind the choices and recommendations; further research might reveal useful insights into distance interviewing generally.

Meanwhile the majority of survey respondents - 61\% - interviewed au pair candidates by online video call, using either Skype or FaceTime. This is not surprising, given the popularity of the technology and the fact that newer entrants, such as Zoom and Google, have come into the market as well. What is noteworthy in the survey results is that, as with email, there was a significant drop-off from "used it" to "would recommend." In contrast to the $61 \%$ who interviewed by video, only 38.1 found the medium best to recommend. Many joined the large (33\%) group recommending an in-person meeting as best.

It is certainly true that no technology can fully replicate a personal encounter, which allows one to use all senses and many means of interacting. But no families in the survey actually used in-person interviews, as they would be very hard to arrange. The main conclusions to draw here are that (a) many families in the survey experienced the constraints and limitations of interviewing by video, but (b) we cannot ignore that video was still the majority choice by a large margin. Interviewing by video can even offer some advantages, such as ability to record and review the session (Deakin \& Wakefield, 2013). With this in mind, the next section shifts to candidate preparation for interviews, with the assumption that they must be ready to participate by video. 


\section{PREPARING CENTRAL EUROPEAN CANDIDATES FOR VIDEO INTERVIEWS}

A basic principle of successful interviewing is to be your "best self" (e.g., Townsend \& Gustar, 2015; Vincent, 2020). In other words, do not try to act as something other or more than you are. It may be apparent that you are pretending, and getting away with the pretense is worse, because the goal is to be chosen for a situation that suits you. Putting forth a false self runs the risk of creating a false match: one in which you will not be happy, nor able to satisfy others (Shapley, 2020). Soon we will see cases in which that was the unfortunate outcome.

Being interviewed is a decisive point in the matching process. Au pair candidates face many challenges in preparing for it, including challenges that they may not know about, if it is their first formal interview. Therefore, the recruiting agency must help them prepare. The key points and guidelines that follow are drawn from a synthesis of multiple academic and general-audience sources, including those cited in the paragraph above, along with others. (e.g., Gilani, 2019; Hanna, 2012; Lo Iacono et al., 2016; Read, 2018; Ryan, 2014; University of Florida, 2020). Topics include use of the video technology as well as principles that apply to all interviews. These are some key points for the recruiting agency to make clear initially:

- Knowing that one should not even try to "put on an act" can be comforting, as it is easier to be natural and authentic. However, presenting one's "best self" does require advance preparation and effort, in order to be sure that one's good qualities are brought out and communicated as well as possible.

- For U.S. markets, interviews will be in English. Prepare candidates by always speaking to them and insisting they answer in English.

- An interview is a two-way process. The candidate should be ready to interview the family, and to watch for whether they are presenting themselves honestly.

- Finally, although young people may think they are fluent in the use of video calling, an interview with people you have never met is different from an informal chat with friends. Have them think about what may be required to communicate at one's best on a screen, through a camera and microphone. 


\section{GUIDELINES FOR THE INTERVIEW ITSELF}

The following guidelines are addressed directly to the candidate. They have to do with specific forms of preparation for the interview and good practice during the interview:

1. Run tests on all equipment and software prior to the time of the interview, in order to assure that no technical malfunctions occur. These can leave a poor impression regardless of the cause.

2. Choose a "business casual" type of attire which offers a professional but relaxed look. Use only clothing and grooming in which you are comfortable, to avoid fussing with clothes or hair during the interview.

3. Turn off all devices that generate sound at least three minutes before the interview starts, so that you are not interrupted. Resist the temptation to check devices during the interview unless requested to do so by the family.

4. Before the interview, take a few moments to collect yourself and remember to breathe. Seeming anxious or nervous can come across as a negative. Parents seek stabilizing influences for their children, so, do whatever works for you in order to be alert and energetic, but firmly grounded.

5. Look directly into the camera, and make a concerted effort to give full attention to the interview. Candidates who seem distracted may be perceived as not focused or as not caring about the job.

6. Remember that nonverbal communication can take place unintentionally. Be mindful of your facial expressions and posture. Also, be alert to the family's nonverbal cues (which in some cases may seem unfamiliar if they are specific to the family's culture).

7. Take notes if you need to; they may be useful to both parties. On Skype and Facetime, notes in the written chat section are saved for future reference.

8. Have a true conversation with the family; be interactive. Long periods of silence will feel awkward, so do what you can to keep the conversation moving. For example, be prepared with a story of your experience working with children.

9. Ask questions about the family's children, and be inquisitive but not invasive. Topics like their favorite subjects in school, 
games, sports, or cartoon characters are ideal. Do not discuss politics, religion, or any topic which might be considered controversial.

10. Ask other questions about the family, and listen carefully without interrupting their answers. It is their chance to help prepare you for living with them as a trusted caregiver.

11. Discuss the daily routine and schedule during the interview, so you can know what to expect.

12. Be sure to outline all major points of your own experience working with children. Whether paid or volunteer, everything in your background relating to child care is potentially valuable.

13. Also be ready to talk about your own family and some experiences growing up. It is a good indicator for many host families about how you will interrelate with their children.

14. One way to build initial trust with the host family's children is by showing them a video. It should be practical and educational but also entertaining.

15. Remember to thank the family for their time and effort at the end of the interview, and message them in writing afterward.

16. When waiting to learn the interview's outcome, follow up through the agency using appropriate channels of communication. Do not reach out directly to the host family without clear instructions. Waiting one or two weeks to hear from the family is reasonable, but the time period specified by the manager should be followed.

\section{INTERVIEW PREPARATION AND CONDUCT FOR THE HOST FAMILY}

Host families also can improve success rates by how they approach the interview process. There are two potentially valuable findings from the survey of U.S. host families, and the first is this: families were asked not only how many candidates they interviewed, but also how many interviews they did with their finalists. Researcher Benjamin Read has found that "serial interviewing" of a subject can be more useful and revealing than a one-off session (Read, 2018), and indeed, successful families in the survey tended to interview an au pair more than once before deciding to choose her. 
The other interesting result came from asking families if they prepared a list of written questions for the interviews. Only about one-third did. $64.3 \%$ conducted their interviews without a written framework. This is somewhat surprising, since the parents in host families tend to be professionals, and most professions require frequent use of written documents, checklists, and the like. The article by Sarah Hando may provide one clue as to why so many host families did not rely on structured Q\&A when interviewing au pairs. The host parents featured in the article were physicians, a profession requiring utmost diligence, yet they spoke of the need to "have a gut feeling" about the right au pair to choose. As the mother explained, "People can say things [in interviews] that end up not being true, but in the end, you can tell if someone's a good person" (Hando, 2017).

In this perspective, an interview is more than simply a process for seeing if the interviewee provides the right answers. It becomes a vehicle for exploring and testing so-called intangibles, such as a person's character and temperament, which affect the nature of the relationship that could be formed with the person. This may also help explain why multiple interviews with an au pair appear to be useful. The family goes further in exploring and perhaps even building the relationship that was begun with the first interview, so that the extended process becomes literally a test "match" and if it feels right, the choice is made to continue the relationship-building by bringing the au pair into the home.

Other interpretations of the data are possible. In any event, the survey results stand as data worth considering in the pursuit of good practice.

\section{RESOLVING AND AVOIDING DISPUTES}

Regardless of efforts exerted to match families with au pairs correctly, the match decided upon may often prove less than ideal. In those cases, management is obliged to step in to resolve certain issues. Findings for this paper show that U.S companies have full- or parttime staff assigned to serve as mediators for specified geographic areas. When significant disputes arise between a host family and au pair, these mediators make personal visits to try to bring the parties 
to agreement. The function is considered so important that a company may not even accept families as clients, initially, if they live in places beyond easy driving distance from a mediator.

One common source of dispute is the scope of work expected from the au pair. This can get tricky, as the definition of an au pair's duties can be construed in many ways. For example, au pairs in the U.S. are not to be employed for general household work other than child care, but opinions may differ on where the line should be drawn (e.g., to what extent does child care include keeping the child's room in good order, or cleaning other parts of the home that the child has used? If the child goes everywhere, does it include cleaning the entire house?). In the United Kingdom, which has few regulations governing the au pair market, au pairs customarily perform both childcare and household chores. Still, University of London professor Rosie Cox reported that her research found many families pushing the customary limits extremely:

It was common for ads to set out duties that went beyond "help" with childcare and housework, including shopping, cleaning windows, caring for relatives' children, waitressing, or cooking for dinner parties, gardening, teaching a child a language, and more. One ad stated that the family wanted an au pair to help with their business as well as "helping to run the home" (Cox, 2018).

Research in another country, Norway, shows that host families and au pairs can sometimes head off potential disputes by writing their own customized "contracts". Researchers Anving and Eldén found a number of experienced host families taking that course: "Mistakes' in the past had taught them to use the contract to ensure that the au pair knew what was expected of her. Contracts could be used to specify work tasks and hours, and sometimes further conditions were added" (Anving \& Eldén, 2016). It could be advisable for families and au pairs in the U.S. to follow this practice, too. They would then have written terms and conditions that are more specific and personalized than those in the standardized contracts they sign with au pair companies.

Findings for this paper, in the U.S., also point to the need to be flexible to a degree. Unusual or unforeseen situations can arise in the course of any family's life, and making on-the-spot adjustments to respond to these events should not be objectionable 
to the au pair, as long as she is treated fairly overall. Unfortunately, however, fair treatment is not always the reality.

Investigative reporter Zack Kopplin did an extensive study of the U.S. au pair industry for the national news outlet Politico. Many au pairs in the United States "have positive experiences", he wrote, but then went on to summarize the bad news he had heard from a variety of sources:

They relay horror stories of au pairs who are overworked, humiliated, refused meals, threatened with arrest and deportation - even victims of theft. Worst of all, they say, complaining about exploitative, unsafe working conditions rarely makes any difference. Sometimes, reporting abuse makes the situation worse (Kopplin, 2017).

Kopplin's article contained specific stories of mistreatment in which the details were similar to those found by academic researchers in the U.K. (Búriková, 2015; Cox, 2018). Similar details included au pairs being expected to work unreasonably long hours (up to 80 or 90 hours a week), not being given adequate or private living space, and having weekly pay withheld. These patterns suggest that mistreatment is not unique to the U.S. They also suggest that failure rates might be reduced by au pair companies doing more to screen out troublesome host families, such as families that view au pairs primarily as cheap labor to be exploited.

However, by no means can all problems be attributed to the host families. On public websites and consumer-protection sites, U.S. families report unacceptable behavior by au pairs. Complaints include au pairs being dishonest, or not wanting to do work that was previously agreed to, or damaging the family home, or being incapable or unwilling to care properly for the children (e.g., Harquail, 2012; Better Business Bureau, 2019). Further, Kopplin obtained a year's worth of data on serious "incident" complaints - the kind that get formally reported to the highest levels within the industry, and often defy resolution. These complaints were initiated almost equally by au pairs and families (Kopplin, 2017).

The main inferences that can be drawn from all this are fairly simple. It does not appear that match failures can be attributed primarily to either the host families or the au pairs. Nor do the studies cited in other sections of this paper point to a single, obvious weak link or "bug" in the system that could be fixed to yield massive 
improvements. Failures are to be expected in any system of human relationships. The situation here is that failures are frequent, and seem to have many possible points of origin, and can have severe consequences. A situation of this type calls for continuous, ongoing improvements in all areas from selection and preparation of participants, to the matching process, follow-up, and conflict resolution. Management methods and technologies used by the companies and recruiting agencies could be key tools for improvement in each area.

\section{DISCUSSION AND CONCLUSIONS}

There are many opportunities for further research on the global au pair industry, and the research could be valuable in multiple respects. The industry is important to people in all parts of the world, and it has unusual features, such as combining the delivery of immediately needed services with expected long-range personal benefits and cultural enrichment. The fact that participants engage for relatively short, defined periods makes it similar to other industries in today's gig economy; the fact that participants literally share resources and activities makes it similar to new industries in the sharing economy.

Yet relatively little research has been done thus far on the actual workings of the system and how they could be improved. Much of the existing literature studied for this paper has been focused on specifics of child care and child development, which is important but no so relevant to management studies. Other research, both academic and journalistic, has focused on matters such as exposing abuses in the system, and their effects on women (e.g., Cox, 2007). The proposed solutions often involve better regulation and oversight (as in Kopplin, 2017), but here again it would be useful to look at things more from a perspective of management and operational systems.

This paper is an initial effort to study the industry from such a perspective. It is necessarily incomplete, due partly to challenges in gathering needed data. For example, Kopplin, despite having the support of a major news organization, was unable to obtain definitive nationwide statistics on the actual failure rate of family-au pair matches in the U.S. Much of the needed information may be either kept confidential in companies' case files or not sufficiently 
tracked and collected to begin with. The survey for this paper has made a contribution by deriving the failure rate in a sample of host families from one au pair company.

As another example: the author came to this research from a particular background in studying and teaching the use of digital technologies in business. Clearly, these technologies are increasingly used in many aspects of the au pair industry - in the online interviews, in companies' search-and-match systems, and more. The paper has contributed some initial insights on their use; much more could be done by researchers looking further into various areas of interest.

In conclusion, the paper is offered as an early step in systematically analyzing the vast and complex global au pair industry, with an eye toward building knowledge of how it currently works and could potentially be improved. It is hoped the findings will be useful to managers and participants, and will inspire other researchers to make many more useful contributions.

\section{ACKNOWLEDGMENTS}

The authors express their gratitude to Dr. Phillip Frese, Dean of the College of Business Administration and Information Science at Clarion University, Juanice Vega, Assistant Dean of the College of Business Administration and Information Science, and to professors in their college for sharing their wisdom during the course of this research. Thanks go as well to Dr. Miguel R. Olivas-Lujan, Teaching Professor in Human Resources Management, School of Labor and Employment Relations, Penn State University for his advice on an earlier version of the manuscript. We also wish to acknowledge Mr. Nick Tiernan, Program Analyst in the U.S. Department of State, as an exemplary public official whose dedication and friendly support has helped to produce good au pair experiences for many. Through the Department's J-1 Visa Exchange Visitor Program (EVP), Mr. Tiernan and his colleagues work with U.S. sponsors of visiting au pairs, students, teachers, professors, and others from countries around the world. Finally, we express our professional gratitude to the researchers and investigative writers cited in the literature review. They have helped to build an understanding of the au pair industry's strengths and shortcomings; our work stands on their shoulders. 


\section{REFERENCES}

Anving, T. \& Eldén, S. (2016). Precarious care labor: Contradictory work regulations and practices for au pairs in Sweden. Nordic Journal of Working Life Studies, 6(4), 29-48. doi: 10.19154/njwls.v6i4.5611.

AuPairCare (2019). Au Pair in the USA: Information on the Program, https:// www.aupair.com/en/p-au-pair-usa-america.php (Accessed: $1^{\text {st }}$ April 2020).

AuPairCare (2020). Benefits of Being an Au Pair in America. AuPairCare by Intrax, https://www.aupaircare.com/au-pairs/program-benefits (Accessed: $1^{\text {st }}$ April 2020).

Better Business Bureau (2019). AuPairCare, Inc.: Complaints, https://www.bbb. org/us/ca/san-francisco/profile/nanny-services/aupaircare-inc-1116-37617/ complaints (Accessed: $2^{\text {nd }}$ April 2020).

Burchinal, M., Magnuson, K., Powell, D. \& Hong, S.S. (2015). Early childcare and education. In: R.M. Lerner (Ed.), Handbook of Child Psychology and Developmental Science ( $7^{\text {th }}$ ed., Vol. 4, pp. 1-45). Hoboken, NJ: John Wiley \& Sons. doi: 10.1002/9781118963418.childpsy406.

Búriková, Z.S. (2015). 'Good families' and the shadows of servitude: Au pair gossip and norms of au pair employment. In: R. Cox (Ed.), Au Pair's Lives in Global Context. Basingstoke: Palgrave Macmillan (pp. 36-52). doi: 10.1057/9781137377487_3.

Cox, R. (2018). Think Uber drivers have it bad? Take a look at au pairs. The Guardian. https://www.theguardian.com/commentisfree/2018/aug/30/au-pairsservants-legal-rights-government.

Cox, R. (2007). The au pair body. European Journal of Women's Studies, 14(3), 281-296. doi: 10.1177/1350506807079015.

Cox, R. (Ed.) (2015). Au Pair's Lives in Global Context: Sisters or Servants? Basingstoke: Palgrave Macmillan. doi: 10.1057/9781137377487.

de Balzac, H. (2010). Pierrette (K.P. Wormeley, Trans.). Project Gutenberg. (Original work published 1840). http://www.gutenberg.org/files/1704/1704h/1704-h.htm.

Deakin, H. \& Wakefield, K. (2013). Skype interviewing: Reflections of two $\mathrm{PhD}$ researchers. Qualitative Research, 14(5), 603-616. doi: 10.1177/ 1468794113488126.

Gilani, A. (2019). In interviews, it's not about 'right' answers. It's about being yourself. Science. https://www.sciencemag.org/careers/2019/04/interviewsit-s-not-about-right-answers-it-s-about-being-yourself.

Go Au Pair (2020a). Au Pair Costs, https://www.goaupair.com/host-families/program-costs/ (Accessed: $2^{\text {nd }}$ April 2020). 
Go Au Pair (2020b). How to Find an Au Pair for Your Family with Go Au Pair, https://www.goaupair.com/host-families/view-au-pairs/ (Accessed: $2^{\text {nd }}$ April 2020).

Hando, S.H. (2017). Cultural Care Au Pair childcare business grows in northeastern Pennsylvania. Times Leader. https://www.timesleader.com/news/643806/ cultural-care-au-pair-childcare-business-grows-in-northeastern-pennsylvania.

Hanna, P. (2012). Using Internet technologies (such as Skype) as a research medium: A research note. Qualitative Research, 12(2), 239-242. doi: 10.1177/1468794111426607.

Harquail, C.V. (2010). Choosing an Au Pair: How Much Does the Home Country Matter? AuPairMom, http://aupairmom.com/choosing-an-au-pair-howmuch-does-the-home-country-matter/2010/04/29/celiaharquail/ (Accessed: $28^{\text {th }}$ March 2020).

Harquail, C.V. (2012). When Your Au Pair Complains about the Schedule. AuPairMom, http://aupairmom.com/when-your-au-pair-complains-about-theschedule/2012/10/31/celiaharquail/ (Accessed: 30 ${ }^{\text {th }}$ March 2020).

Hess, S. \& Puckhaber, A. (2004). 'Big sisters' are better domestic servants?! Comments on the booming au pair business. Feminist Review, 77(1), 65-78. doi: 10.1057/palgrave.fr.9400177.

IAPA (2018). New Au Pair Survey: Number of Au Pairs in Germany at An AllTime High. International Au Pair Association. https://www.iapa.org/newau-pair-survey-number-of-au-pairs-in-germany-at-an-all-time-high.

Kannon, J. \& Gedarovich, R. (2009). Au Pair in America offers child care industry's first protection plan against job loss. PBN Connect. Providence Business News. http://pbn.com/au-pair-in-america-offers-child-care-industrysfirst-protection-plan-against-job-loss40837.

Kopplin, Z. (2017). 'They think we are slaves'. POLITICO Magazine. https://www. politico.com/magazine/story/2017/03/au-pair-program-abuse-state-department-214956.

Lo Iacono, V., Symonds, P. \& Brown, D.H. (2016). Skype as a tool for qualitative research interviews. Sociological Research Online, 21(2), 103-117. doi: $10.5153 /$ sro.3952.

Lo, J. (2020). Five Reasons You Should Consider a Male Au Pair. InterExchange, https://www.interexchange.org/articles/au-pair-usa/five-reasons-youshould-consider-hosting-a-male-au-pair/ (Accessed: $7^{\text {th }}$ April 2020).

Prowork Au Pair (n.d.). Prowork Au Pair \& Nanny Agency Poland - Agencja Au Pair, Warszawa Polska, https://www.aupair.com/pl/agencja-prowork-aupair-nanny-agency-poland/index.php (Accessed: $6^{\text {th }}$ April 2020). 
Read, B.L. (2018). Serial interviews: When and why to talk to someone more than once. International Journal of Qualitative Methods, 17(1). doi: 10.1177/1609406918783452.

Ryan, L. (2014). Can you be yourself on a job interview? Forbes. https://www.forbes. com/sites/lizryan/2014/05/05/can-you-be-yourself-on-a-job-interview.

Shapley, A. (2020). Jobseekers - You Really Do Need to Be Yourself in the Interview. Hays, https://social.hays.com/2018/04/05/be-yourself-interview/ (Accessed: $1^{\text {st }}$ April 2020).

Slevin, C. (2019). Au pairs win $\$ 65.5$ million settlement in Denver lawsuit. Associated Press. https://apnews.com/23db59461513473c900f6695b08e0e96.

Steiber, A. \& Alänge, S. (2016). A special breed of people. In: The Silicon Valley Model (pp. 65-85). Springer Link. doi: 10.1007/978-3-319-24921-6_5.

Townsend, M. \& Gustar, G. (2015). Week 7: Presenting Your 'Best' Self at Interview. The Open University. https://www.open.edu/openlearn/ocw/mod/oucontent/view.php?id=20012\&printable=1 (Accessed: $1^{\text {st }}$ April 2020).

University of Florida (2020). How to Be Yourself During the Job Interview. University of Florida, College of Journalism and Communications, https://onlinemasters.jou.ufl.edu/be-yourself-job-interview/ (Accessed: 18 ${ }^{\text {th }}$ March 2020).

U.S. Bureau of Educational and Cultural Affairs (2019). Au Pair Category, https:// j1visa.state.gov/wp-content/uploads/2019/03/Au-Pair-Flyer-2018-web.pdf (Accessed: 30 ${ }^{\text {th }}$ March 2020).

U.S. Census Bureau (2019). American Community Survey Data, https://www.census.gov/programs-surveys/acs/data.html (Accessed: 30 ${ }^{\text {th }}$ March 2020).

Vincent, M.J. (2020). Expressing Your Best Authentic Self. Career Coach Monterey, https://careercoachmonterey.com/expressing-your-best-authentic-self/ (Accessed: $1^{\text {st }}$ April 2020).

Yodanis, C. \& Lauer, S.R. (2005). Foreign visitor, exchange student, or family member? A study of au pair policies in the United States, United Kingdom, and Australia. International Journal of Sociology and Social Policy, 25(9), 41-64. doi: 10.1108/01443330510791171. 


\title{
ZWIĘKSZENIE JAKOŚCI ZARZĄDZANIA I PRAKTYK BIZNESOWYCH W BRANŻY OPIEKI NAD DZIEĆMI (AU PAIR). PRZEGLACD SYSTEMOWY, Z PERSPEKTYWY EUROPY ŚRODKOWEJ I USA
}

\begin{abstract}
Abstrakt
Praca w branży au pair na terenie USA wiąże się z rekrutacją osób w wieku 18-26 lat także na terenie Europy Środkowej. Dobrze przeprowadzona rekrutacja to korzyści dla obu stron (pracownika i pracodawcy): z jednej strony mamy rozwijająca pracownika wymianę kulturalna, z drugiej realizację potrzebnej pracy. Niestety w ponad jednej czwartej przypadków badanych (w niniejszym tekście), mamy do czynienia $\mathrm{z}$ zaburzeniami $\mathrm{w}$ relacjach pracownika $\mathrm{z}$ agencja zatrudniająca i/lub rodzina, dla której świadczy się pracę - co kończy się często wcześniejszym zakończeniem pobytu, niż zakontraktowano. Tego rodzaju „awarie” sa szkodliwe dla zaangażowanych osób, a także dla centrali europejskich agencji rekrutacyjnych i amerykańskich firm, z którymi współpracuja. W niniejszym artykule przeanalizowano, w jaki sposób można poprawić wskaźniki sukcesu poprzez lepsze praktyki wszystkich zainteresowanych. Czynniki sukcesu obejmują: ustalanie realistycznych oczekiwań wobec kandydatów au pair i rodzin goszczacych, treningi online dla kandydatów do pracy oraz zapewnienie silnego wsparcia ze strony agencji zatrudniającej już po rozpoczęciu pracy w rodzinie. Prezentowane w tekście prace badawcze obejmowały bezpośrednie badanie amerykańskich rodzin goszczących i badania porównawcze źródeł, takich jak raporty prasowe, publikacje akademickie, publiczne strony internetowe używane w przemyśle au pair w Europie Wschodniej.
\end{abstract}

Tło. Tło artykułu stanowią kulturowe i organizacyjne bariery występujące w branży au pair, które blokuja obustronnie korzystną współpracę pracodawcy (agencji oraz rodziny) i pracownika (młodych osób z Europy Wschodniej). W tekście, na podstawie prowadzonych badań proponowane są środki zaradcze odnośnie do tej sytuacji.

Cele badawcze. Celem niniejszego artykułu było zidentyfikowanie wybranych barier organizacyjnych i kulturowych związanych z budowaniem współpracy biznesowej w branży au pair. Cele badawcze wynikały z faktu, iż wstępne rozpoznanie pola badawczego wskazywało na istniejaccy paradoks: obustronnie korzystna współpraca była w zaskakująco dużej liczbie przypadków przerywana.

Metodologia. Badanie amerykańskich rodzin goszczacych (123 wywiady online) połaczone $\mathrm{z}$ literaturowymi badaniami porównawczymi pochodzacymi z wielu źródeł: publikacje akademickie, raporty prasowe, publiczne strony internetowe z branży au pair.

Kluczowe wnioski. W niniejszym artykule zidentyfikowano trzy znaczace dla branży au pair elementy mogące prowadzić do dłuższej współpracy, a tym samym tworzenia wartości dodanej pochodzącej z kooperacji biznesowej. Wymienione elementy sukcesu we współpracy obejmują: ustalanie realistycznych oczekiwań 
wobec kandydatów do pracy w charakterze au pair ze strony rodzin goszczących oraz kandydatów do pracy wobec rodzin; szkolenie online poprzez rozmowy „na żywo" - poprzedzajace przyjazd; zapewnienie silnego wsparcia ze strony organizacji zatrudniającej już po przyjeździe do rodziny. Powyższe trzy elementy ważne dla długoterminowej współpracy mogą być ważne nie tylko dla rynku au pair, ale i dla tych rodzajów prowadzenia działalności gospodarczej, gdzie mamy do czynienia z różnicami międzykulturowymi oraz w pracą bezpośrednim kontakcie z klientem (np. przemysł czasu wolnego).

Słowa kluczowe: przemysł czasu wolnego, współpraca międzykulturowa, branża au pair, globalizacja. 


\section{APPENDIX A}

\section{(Survey tables, Charts, Statistical Summation)}

\section{Frequency Table}

\begin{tabular}{|l|c|c|c|c|}
\hline \multicolumn{5}{|c|}{ Interviewed } \\
\hline Valid & Frequency & Percent & Valid Percent & $\begin{array}{c}\text { Cumulative } \\
\text { Percent }\end{array}$ \\
\hline 1 au pair & 18 & 14.6 & 14.6 & 14.6 \\
\hline 2 au pairs & 39 & 31.7 & 31.7 & 46.3 \\
\hline 3 au pairs & 18 & 14.6 & 14.6 & 61.0 \\
\hline 4 au pairs & 26 & 21.1 & 21.1 & 82.1 \\
\hline 5 au pairs & 22 & 17.9 & 17.9 & 100.0 \\
\hline Total & 123 & 100.0 & 100.0 & \\
\hline
\end{tabular}

Summary: Most host families $(39,31.7 \%)$ interviewed 2 au pairs before hiring one, followed by 26 (21.1\%) who interviewed 4 au pairs, then $22(17.9 \%)$ who interviewed 5 au pairs.

\begin{tabular}{|l|r|r|r|c|}
\hline \multicolumn{5}{|c|}{ Hired } \\
\hline Valid & Frequency & Percent & Valid Percent & $\begin{array}{c}\text { Cumulative } \\
\text { Percent }\end{array}$ \\
\hline 1 au pair & 29 & 23.6 & 23.6 & 23.6 \\
\hline 2 au pairs & 27 & 22.0 & 22.0 & 45.5 \\
\hline 3 au pairs & 4 & 3.3 & 3.3 & 48.8 \\
\hline 4 au pairs & 21 & 17.1 & 17.1 & 65.9 \\
\hline 5 au pairs & 6 & 4.9 & 4.9 & 70.7 \\
\hline 6 au pairs & 10 & 8.1 & 8.1 & 78.9 \\
\hline 7 au pairs & 9 & 7.3 & 7.3 & 86.2 \\
\hline 8 au pairs & 9 & 7.3 & 7.3 & 93.5 \\
\hline 9 au pairs & 2 & 1.6 & 1.6 & 95.1 \\
\hline 10 au pairs & 1 & 0.8 & 0.8 & 95.9 \\
\hline 12 au pairs & 3 & 2.4 & 2.4 & 98.4 \\
\hline 14 au pairs & 1 & 0.8 & 0.8 & 99.2 \\
\hline 16 au pairs & 1 & 0.8 & 0.8 & 100.0 \\
\hline Total & 123 & 100.0 & 100.0 & \\
\hline
\end{tabular}

Summary: Most host families $(29,23.6 \%)$ hired only 1 au pair in the last 7 years, followed by $27(22.0 \%)$ who hired 2 au pairs, then 21 (17.1\%) who hired 4 au pairs. 


\begin{tabular}{|l|c|c|c|c|}
\hline \multicolumn{5}{|c|}{ Methods } \\
\hline Valid & Frequency & Percent & Valid Percent & $\begin{array}{c}\text { Cumulative } \\
\text { Percent }\end{array}$ \\
\hline Skype & 51 & 41.5 & 41.5 & 41.5 \\
\hline Phone & 14 & 11.4 & 11.4 & 52.8 \\
\hline Text & 10 & 8.1 & 8.1 & 61.0 \\
\hline Email & 24 & 19.5 & 19.5 & 80.5 \\
\hline Face Time & 24 & 19.5 & 19.5 & 100.0 \\
\hline Total & 123 & 100.0 & 100.0 & \\
\hline
\end{tabular}

Summary: Most host families (51, 41.5\%) used Skype for interviews, followed by $24(19.5 \%)$ who conducted interviews using email \& Face Time.

\begin{tabular}{|l|c|c|c|c|}
\hline \multicolumn{1}{|c|}{ Questions } & & & & \\
\hline Valid & Frequency & Percent & Valid Percent & $\begin{array}{c}\text { Cumulative } \\
\text { Percent }\end{array}$ \\
\hline YES & 45 & 36.6 & 36.6 & 36.6 \\
\hline NO & 78 & 63.4 & 63.4 & 100.0 \\
\hline Total & 123 & 100.0 & 100.0 & \\
\hline
\end{tabular}

Summary: Most host families $(78,63.4 \%)$ did not prepare questions prior to interviewing au pairs, while $45(36.6 \%)$ did prepare.

\begin{tabular}{|l|r|r|r|c|}
\hline \multicolumn{5}{|c|}{ Recommendations } \\
\hline Valid & Frequency & Percent & Valid Percent & $\begin{array}{c}\text { Cumulative } \\
\text { Percent }\end{array}$ \\
\hline Skype & 22 & 17.9 & 17.9 & 17.9 \\
\hline Phone & 9 & 7.3 & 7.3 & 25.2 \\
\hline Text & 21 & 17.1 & 17.1 & 42.3 \\
\hline Email & 5 & 4.1 & 4.1 & 46.3 \\
\hline Face Time & 25 & 20.3 & 20.3 & 66.7 \\
\hline Meeting In Person & 41 & 33.3 & 33.3 & 100.0 \\
\hline Total & 123 & 100.0 & 100.0 & \\
\hline
\end{tabular}

Summary: Most host families $(41,33.3 \%)$ recommend interviewing au pairs by meeting them in person, followed by 25 (20.3\%) via Face Time, then 22 (17.9\%) via Skype. 


\section{Bar Charts}

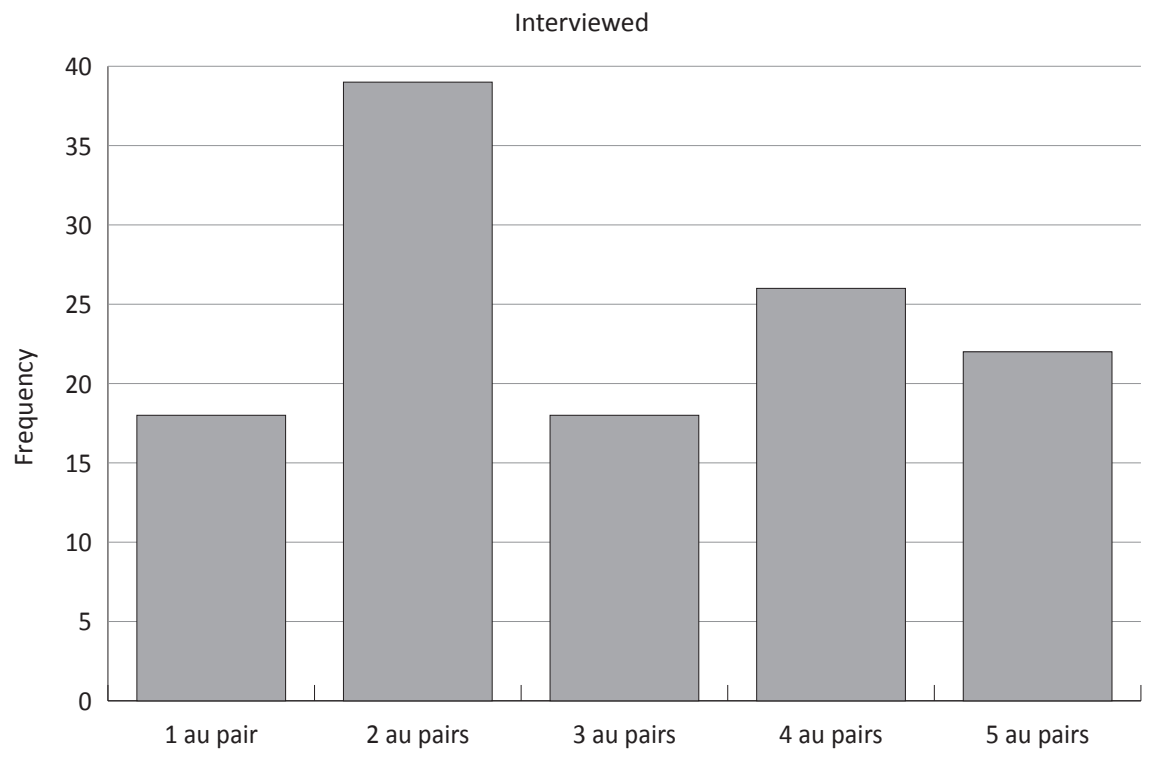

Summary: Most host families interviewed 2 au pairs before hiring one, followed by 4 , then 5 .

Hired

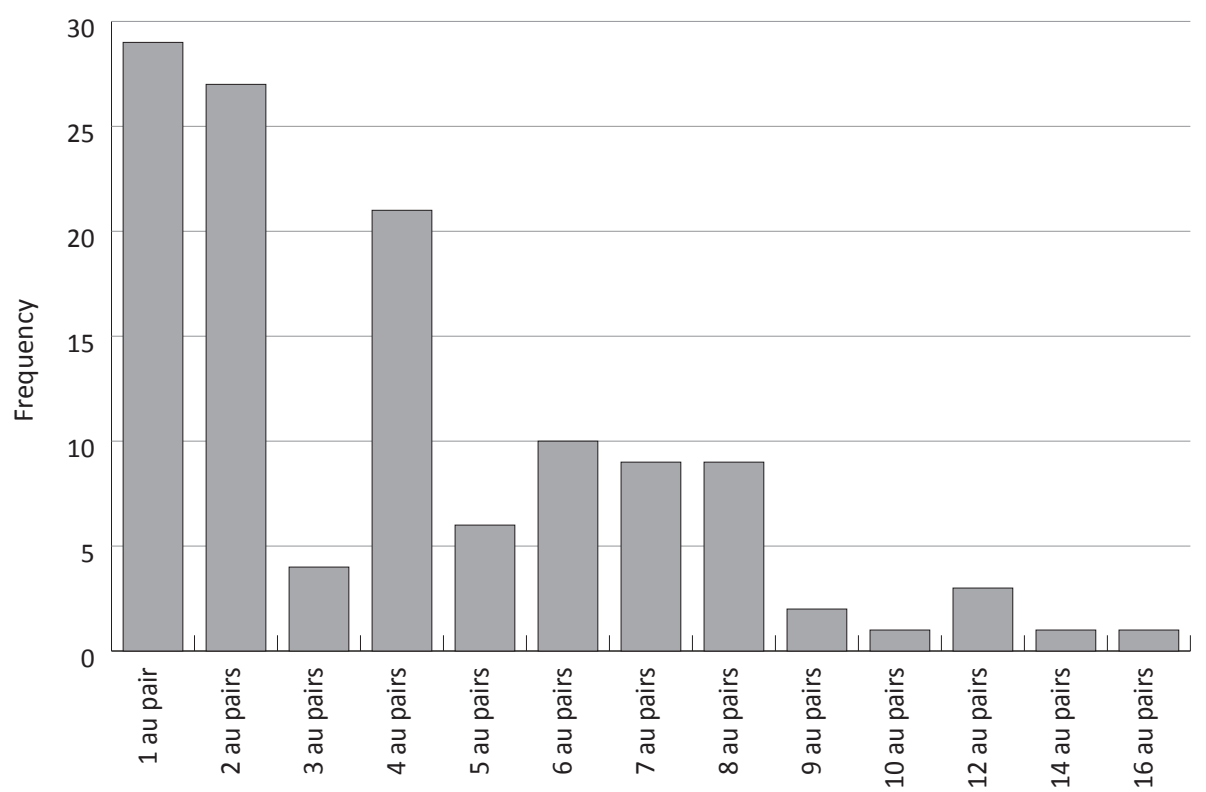

Summary: Most host families hired only 1 au pair in the last 7 years, followed by 2 , then 4 . 


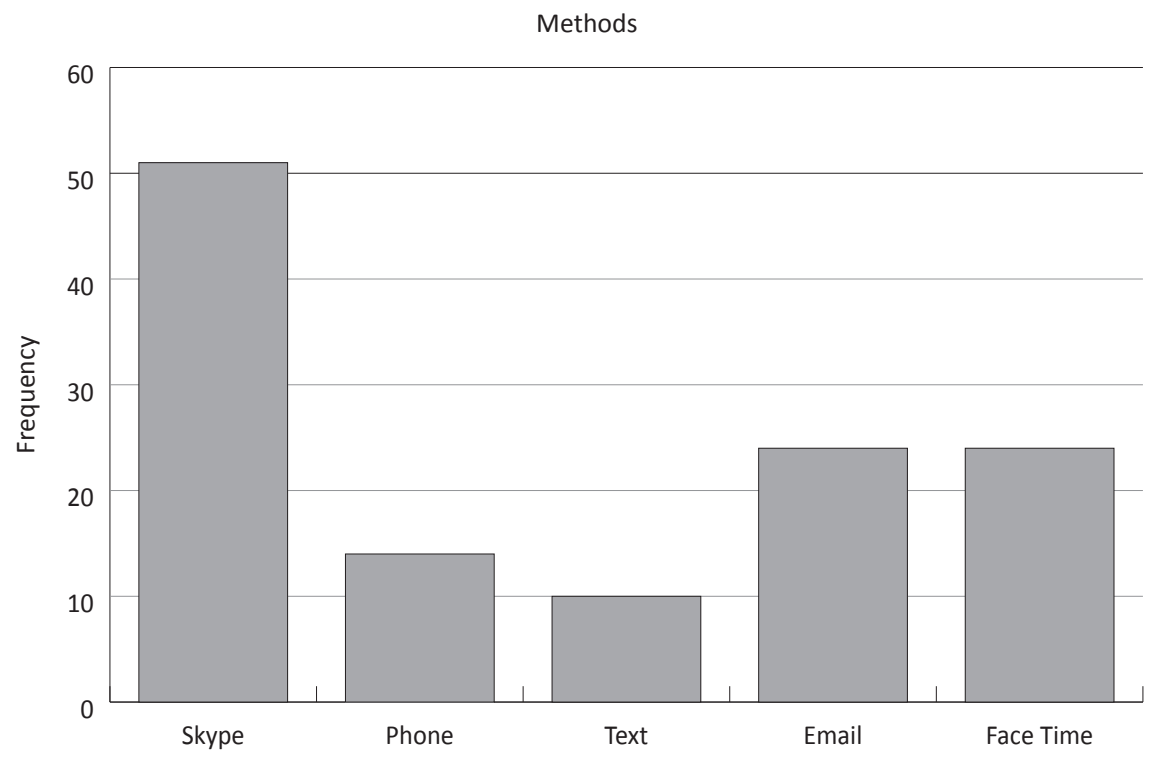

Summary: Most host families used Skype for interviews, followed equally by Email \& Face Time.

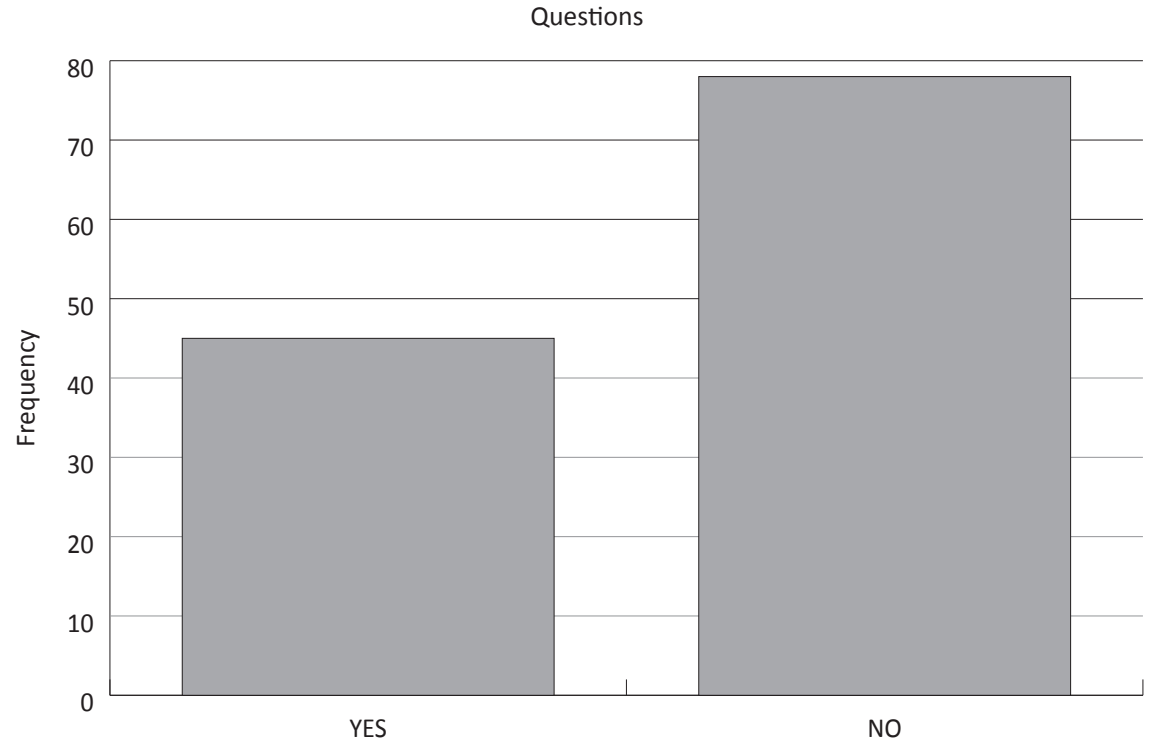

Summary: Most host families did not prepare questions prior to interviewing au pairs. 


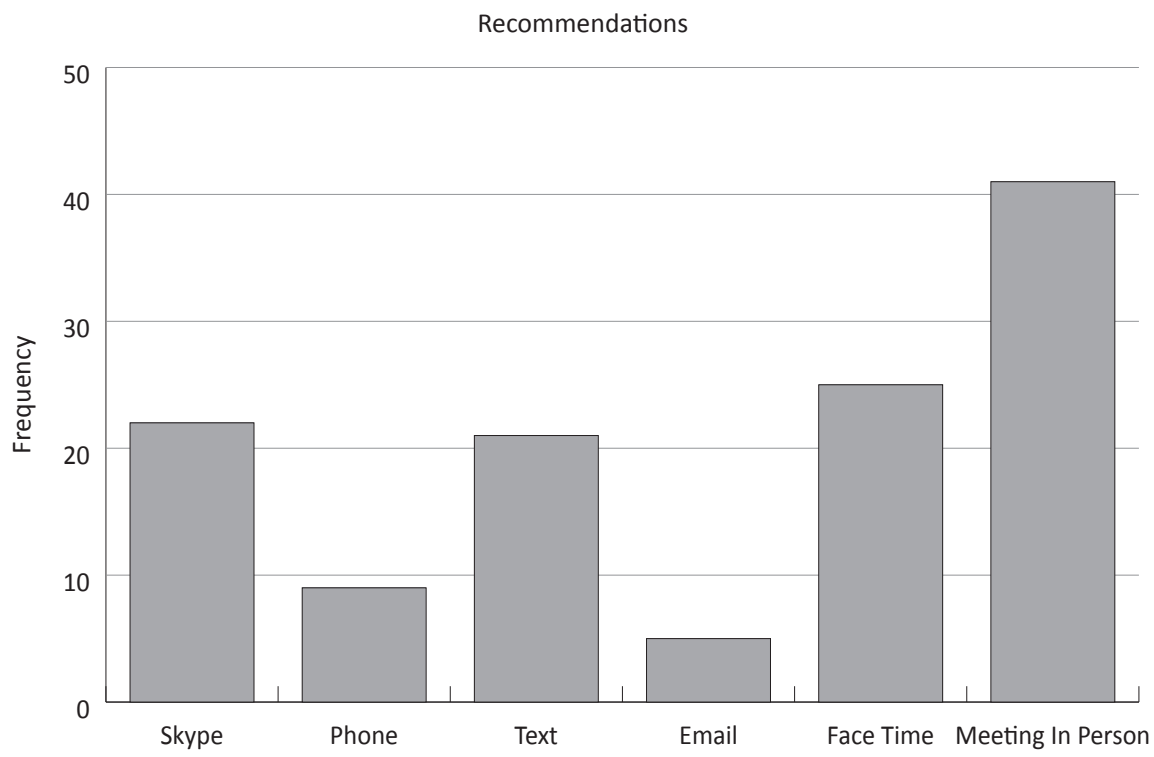

Summary: Most host families recommended interviewing au pairs by meeting in person, followed by Face Time, then Skype.

\section{Statistical Summation}

Most host families (39, 31.7\%) interviewed only 2 au pairs before hiring one to provide childcare for their children. 78 (63.4\%) did not prepare questions prior to the interview. The most frequently used method of interviewing au pairs conducted by 51 host families (41.5\%) was Skype. Although the most highly recommend interview method by 41 host families (33.3\%) was meeting au pairs in person, followed by Face Time (25, 20.3\%).

Interestingly 56 host families (45.5\%) hired only 1 au pair (29, $23.6 \%)$ or $2(27,22.0 \%)$ in the last 7 years. Perhaps their childcare needs were no longer required, or the family financial situation changed, etc. - no data is available to determine the reason for discontinuing childcare. Typically, an au pair is hired for a period of one year, although it can be extended up to a maximum of 2 years. 21 host families (17.1\%) hired 4 au pairs, for periods of service which could have continued up to 7 years with extensions. In addition, 28 host families (22.8\%) hired 6-8 au pairs in the last 7 years or about one per year. 